\title{
Antioxidant and antibacterial screening of honey of Hiterotrogona itama collected from different meliponiculture areas in East Kalimantan, Indonesia
}

\author{
SUROTO HADI SAPUTRA ${ }^{1, \boldsymbol{v}}$, BERNATAL SARAGIH ${ }^{2}$, IRAWAN WIJAYA KUSUMA ${ }^{1}$, \\ ENOS TANGKE ARUNG ${ }^{3, \vee \varphi}$ \\ ${ }^{1}$ Faculty of Forestry, Universitas Mulawarman. Jl. Kuaro, Samarinda 75123, East Kalimantan, Indonesia. Tel.: +62-541-749343, \\ vemail: surotohs.65@gmail.com \\ ${ }^{2}$ Faculty of Agriculture, Universitas Mulawarman. Jl. Pasir Belengkong, Samarinda 75123, East Kalimantan, Indonesia \\ ${ }^{3}$ Laboratory of Forest Product Chemistry Faculty of Forestry, Universitas Mulawarman. Jl. Ki Hajar Dewantara, Gunung Kelua, Samarinda 75123, \\ East Kalimantan, Indonesia. Tel.: +62-541-737081, ^vemail: tangkearung@fahutan.unmul.ac.id
}

Manuscript received: 19 October 2021. Revision accepted: 22 November 2021.

\begin{abstract}
Saputra SH, Saragih B, Kusuma IW, Arung ET. 2021. Antioxidant and antibacterial screening of honey of Hiterotrogona itama collected from different meliponiculture areas in East Kalimantan, Indonesia. Nusantara Bioscience 13: 232-237. Heterotrigona itama (Cockerell, 1918) is a stingless bee in several areas in East Kalimantan of Indonesia. This study aimed to analyze the phytochemicals and antioxidant activity of honey of this stingless bee from several regions in East Kalimantan. Phytochemical testing was carried out qualitatively, while antioxidant activity was performed using DPPH (1.1-diphenyl-2-picrylhydrazyl-radical) radical scavenging assay. Furthermore, the antimicrobial activity of Staphylococcus aureus and Escherichia coli was performed through in vitro tests. The results showed that the honey of stingless $H$. itama bee collected from five cultivated areas in East Kalimantan contained flavonoids, coumarin, steroids, and carotenoids, some of which had alkaloids and tannin compounds. The antioxidant activity (IC 50 ) was observed between 43,54 ppm-71,27 ppm, while the strong antimicrobial activity of this honey was found against S. aureus and E. coli.
\end{abstract}

Keywords: Antimicrobial, antioxidant, honey, Hiterotrogona itama, stingless bees, phytochemicals

\section{INTRODUCTION}

East Kalimantan, Indonesia, consists of three cities: Samarinda, Kutai Kartanegara, and Bontang, and seven districts, Kutai Kartanegara, Kutai Timur, Kutai Barat, Tanjung Redeb, Tanjung Selor, Paser, Penajam Paser Utara and Mahakam Hulu. East Kalimantan forest is a tropical rainforest with vast biodiversity, one of which is the potential for stingless (Apis spp.) and stingless honey bees (Trigona spp.). There are many stingless honey bees (Trigona spp.) types, including $T$. itama, $T$. incisa, $T$. apicalis, T. melina, T. fuscibasis, T. fuscobalteata, $T$. laeviceps, T. drescheri, and T. terminate. As per Syafrizal et al. (2014), T. itama or also known as Heterotrigona itama (Cockerell, 1918), is one of the types of Trigona currently being farmed by honey breeders (meliponiculture), is because of their larger size, ease of adaption and production of more honey. According to Jayadi and Susandarini (2020), honey is a natural product with various benefits commonly used as food sweeteners, health supplements, and traditional medicine.

Heterotrigona itama from Samarinda and Tarakan has primary and secondary metabolic compounds between other tannins, alkaloids, flavonoids, coumarins, and carbohydrates. $H$. itama from Samarinda has saponin compounds, while Tarakans' has no saponin compounds. Both H. itama from Samarinda and Tarakan has no triterpenoid, steroid, and carotenoid compounds. $H$. itama from Samarinda and Tarakan also has antioxidant activity (Syafrizal et al. 2020).

In East Kalimantan, several areas have meliponiculture without $H$. itama, including Samarinda, Kutai Kartanegara, Penajam Paser Utara, Paser, Kutai Timur, Tanjung Redeb and Tanjung Selor. However, to the author's knowledge, no one has conducted research comparing the phytochemical, antimicrobial, and antioxidant $H$. itama honey from several East Kalimantan areas with different habitats. For this reason, this study was conducted to analyze the phytochemical, antioxidant, and antimicrobial activity of honey of $H$. itama collected from several regions in East Kalimantan.

\section{MATERIALS AND METHODS}

\section{Location of a research area}

The honey sampling location was; Tanah Merah Village (Rimbawan Dalam Hamlet) (Samarinda City), Buana Jaya Village (Kutai Kartanegara District), Karya Merdeka Village (Kutai Kartanegara District), Penajam Village (Penajam Paser Utara District) and Saing Prupuk Village (Aper Sejahtera Farmer Group) (Paser District) in East Kalimantan Province, Indonesia. The honey sampling location is presented in Figure 1.

In Tanah Merah, Samarinda, H. itama honey samples were taken on vegetation consisting of Carex pendula, 
Acacia auriculiformis, Erysimum pieninicum, Ficus fraseri, Musa ornata, in the photographs of the sampling location Samarinda along with honey unit setup are presented in Figure 2.A. In Buana Jaya, Kutai Kartanegara, location has vegetation including Acacia mangium, Aechmeae sp.,
Asystasia gangetica, Betula humilis, Ceiba pentandra, Elaeis guineensis, E. pieninicum, Hibiscus rosasinensis, Jacaranda obtusifolia, Jasminum sambac, Leucaena leucocephala, Phyllantus sp., Trichosanthes sp., Tamarindus indica, Lycopus indica and Lycopus lucidis (Figure 2.B).

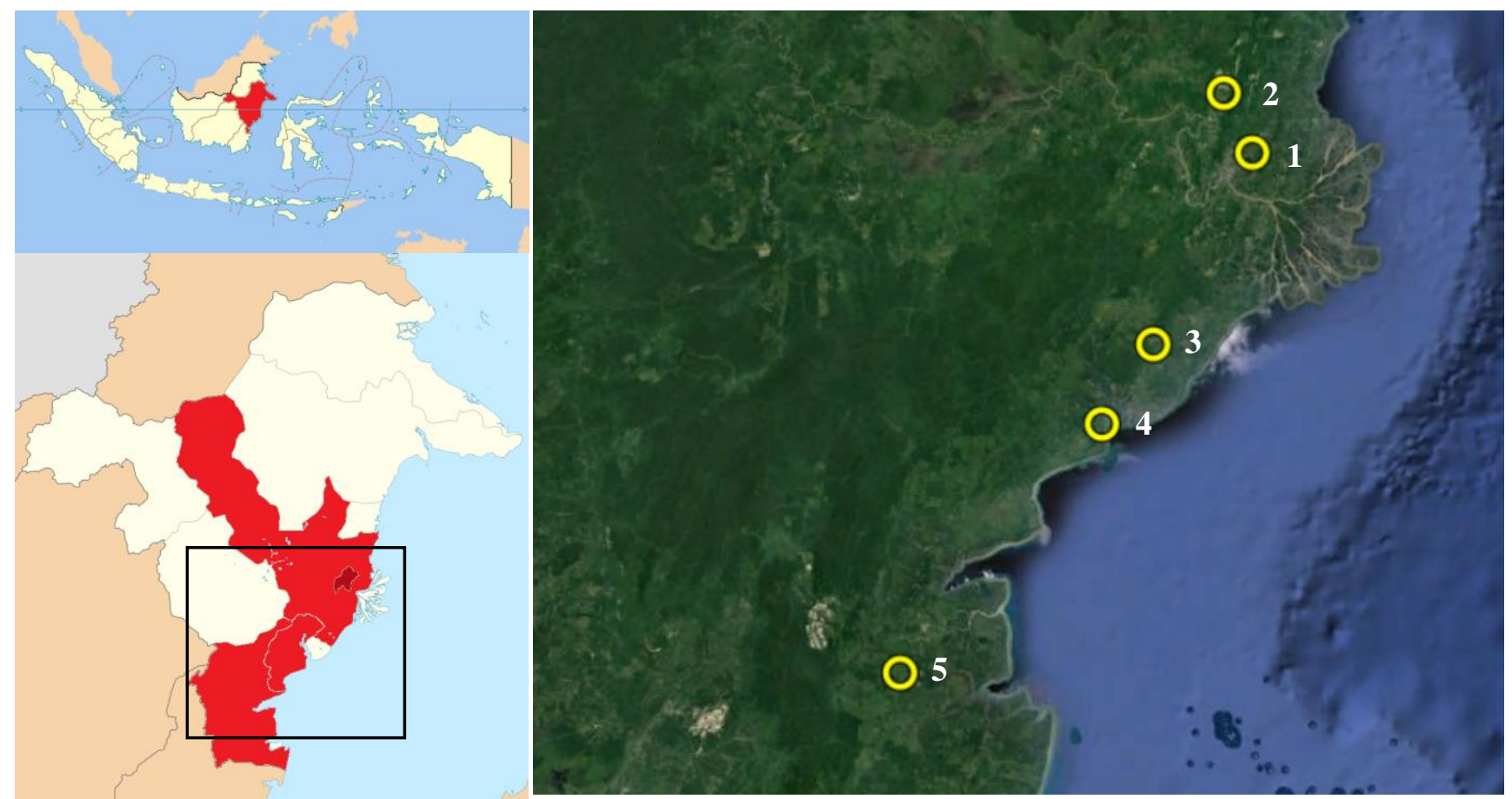

Figure 1. Location of Heterotrigona itama honey sampling (Stingless bee honey) from five regions in East Kalimantan, Indonesia. 1. Tanah Merah Village, Samarinda, 2. Buana Jaya Village, Kutai Kartanegara, 3. Karya Merdeka Village, Kutai Kartanegara, 4. Penajam Village, Penajam Paser Utara, 5. Saing Prupuk Village, Paser

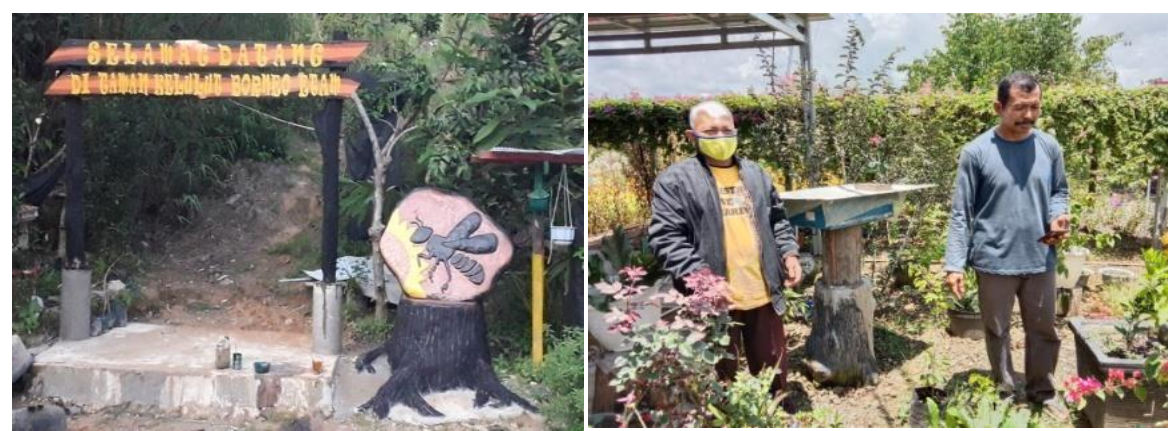

B

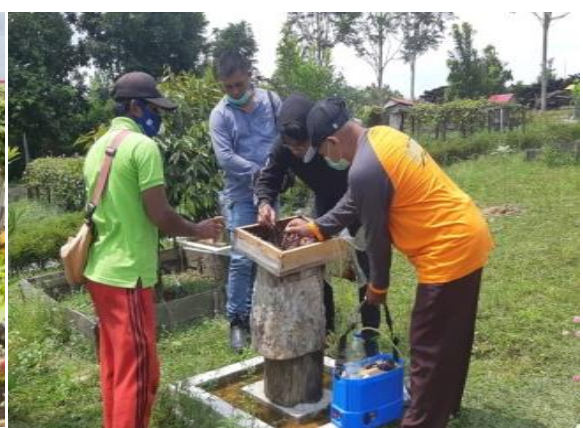

C

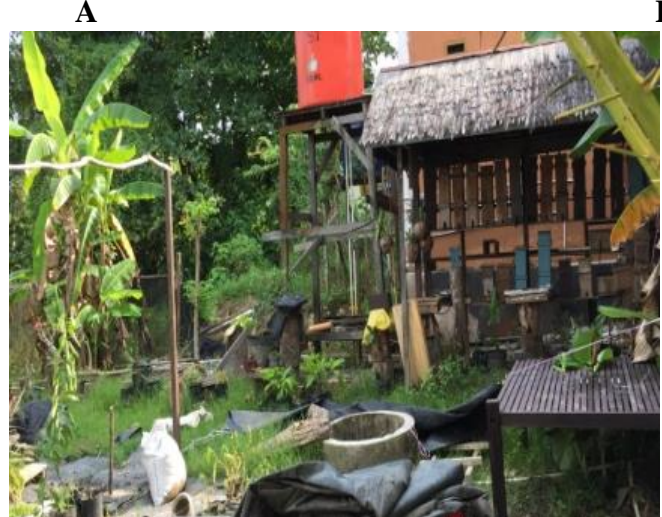

D

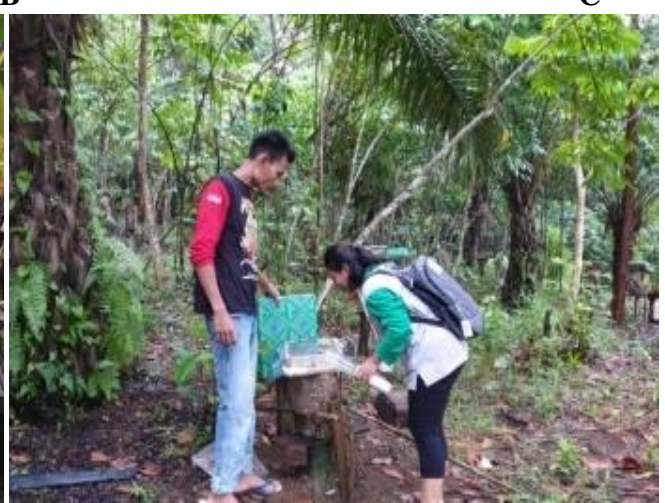

$\mathbf{E}$

Figure 2. Sampling area of Heterotrigona itama honey on; A. Tanah Merah Village, Samarinda, B. Buana Jaya Village, Kutai Kartanegara, C. Karya Merdeka Village, Kutai Kartanegara, D. Penajam Village, Penajam Paser Utara, E. Saing Prupuk Village, Paser, East Kalimantan, Indonesia 
The location of Karya Merdeka, Kutai Kartanegara consists of vegetation such as Agelaea pentagyna, Artemisia annua, Averrhoa carambola, Combretum goldieanum, Cistus asper, F. fraseri, Melastoma malabathricum, Sauropus androgynous, Rhodomyrtus tomentosa, Bidens pilosa, Psychotria fractinervata, E. guineensis, and Pigafetta elata (Figure 2.C). Similarly, Penajam, Penajam Paser Utara, location has vegetation, namely C. pendula, A. gangetica, Solanum melongena, Musa sp., Cosmos sulphureus, Synedrella nodiflora, Apocynaceae (sp1), Syzygium sp., Antiaris toxicaria, $C$. goldieanum, Chamaerops humilis, E. guineensis and A. mangium (Figure 2.D). The vegetation of Saing Prupuk Village, Paser location consists of A. carambola, B. pilosa, Ageratum conyzoides, Kleinhovia hospita, Syzygium rosasinensis, Morus alba, and A. mangium (Figure 2.E).

Honey samples of $H$. itama were taken from honey breeders by suction using a honey vacuum suction device. Honey is packaged in $250 \mathrm{~mL}$ or $500 \mathrm{~mL}$ plastic bottles. The bottles were lined with aluminum sheets to protect them from light and moisture protection and then put in a styrofoam box. The honey styrofoam box was placed in a room in the refrigerator to avoid direct sunlight before analyzing it according to the predetermined parameters.

\section{Reagents used}

Hydrochloric Acid (Merk, $\mathrm{HCl}$ ), Dragendorff, Lead Acetate (Merk, $\mathrm{PbCH}_{3} \mathrm{COO}$ ), Sodium Hydroxide (Merk, $\mathrm{NaOH}$ ), Sulfuric Acid (Merk, $\mathrm{H}_{2} \mathrm{SO}_{4}$ ), Acetone (Merk, $\mathrm{C}_{3} \mathrm{H}_{6} \mathrm{O}$ ), Ethanol (Merk, $\mathrm{CH} 2 \mathrm{OH}$ ), Vitamin C, 2,2diphenyl-1-picrylhydrazyl (DPPH), Nutrient Broth (NB), and chloramphenicol $\left(\mathrm{C}_{11} \mathrm{H}_{12} \mathrm{Cl}_{2} \mathrm{~N}_{2} \mathrm{O}_{5}\right)$.

\section{Phytochemical analysis}

Qualitative phytochemical analysis was performed to determine the presence or absence of chemical compounds of alkaloids, tannins, flavonoids, triterpenoids, steroids, carotenoids, and coumarin. For alkaloid analysis, $5 \mathrm{~mL}$ of honey was carefully mixed with $2 \mathrm{~mL}$ of $\mathrm{HCl}$ in a test tube, and then $1 \mathrm{~mL}$ of Dragendorff was added. The formation of yellow deposits indicated the presence of alkaloids in honey (Oscar et al. 2020). In tannin analysis, honey (1 mL) was mixed with three freshly prepared $1 \%$ lead acetate drops. The formation of a yellow precipitate was considered a positive test for the presence of tannins (Oscar et al. 2020). In flavonoid analysis, $1 \mathrm{~mL}$ of honey was tested with 5 drops of 1 sodium hydroxide solution. The formation of a dark yellow color, followed by a colorless solution formed by adding dilute acid $(1 \% \mathrm{HCl})$, indicated the presence of flavonoids in honey (Viji et al. 2013). Triterpenoid and steroid were analyzed by mixing ten drops of acetic anhydride and two drops of concentrated sulfuric acid treated with $1 \mathrm{~mL}$ of honey diluted in acetone. The resulting mixture was vigorously shaken. Red or purple discoloration indicated triterpenoids, while greenish-blue indicated steroids' presence (Oscar et al. 2020). In carotenoid analysis, $1 \mathrm{~mL}$ of honey was diluted with $5 \mathrm{~mL}$ of chloroform in a test tube, shaken vigorously, and four drops of $8 \%$ sulfuric acid were added. The blue color on the surface of the mixture indicated the presence of carotenoids (Viji et al. 2013). For coumarin analysis, $1 \mathrm{~mL}$ of honey was treated with four drops of sodium hydroxide and alcohol. The solution turned yellow, indicating the presence of coumarin (Viji et al. 2013).

\section{Antioxidant activity analysis}

The DPPH test was carried out as Arung et al. (2015) described by analyzing antioxidant activity for this $500 \mu \mathrm{L}$ $60 \mu \mathrm{M}$ DPPH and $467 \mu \mathrm{L}$ ethanol were used as working solutions. The positive control in this test was Vitamin $\mathrm{C}$ at $100 \mathrm{mg} / \mathrm{mL}$. The honey concentration was $100 \%$ (pure honey or without mixing with any solvent), $75 \%, 50 \%$, and $25 \%$ (the honey mixed with water solvent), and immediately blended into the working solution.

The free radical scavenging effect of honey on the measured concentration differed from the DPPH test using absorption spectrophotometry at a wavelength of $517 \mathrm{~nm}$ (Jun et al. 2003). The attention required to obtain $50 \%$ inhibition is the $\mathrm{IC}_{50}$ value, which is used as a parameter to express the relative antioxidant capacity of honey. The estimated $\mathrm{IC}_{50}$ value was obtained by linear regression analysis in percent $(\%)$ inhibition in response to increasing honey concentration.

\section{Antibacterial analysis}

One $\mathrm{mL}$ sample of honey was put into a microtube for analyses of antimicrobial activity that had been prepared and put into a petri dish as much as $20 \mathrm{~mL}$ and allowed to harden. Then $100 \mu \mathrm{L}$ of bacterial suspension was added, leveled using a cotton swab, and let dry for 15 minutes. After solidifying the media, six wells were made with the help of a sterilized cork borer filled with a sample of 20 $\mu \mathrm{L}$. At the same time, one hole was dropped with $20 \mu \mathrm{L}$ of chloramphenicol as a positive control; one hole was dropped with $20 \mu \mathrm{L}$ acetone as a negative control. Petri dishware was then incubated at $37^{\circ} \mathrm{C}$ for $18-24$ hours after it was measured using rules on the diameter $(\mathrm{mm})$ of the clear zone around the hole, indicating the area of inhibition against bacteria Staphylococcus aureus and Escherichia coli.

\section{RESULTS AND DISCUSSION}

\section{Phytochemical analysis}

Phytochemical analysis was carried out qualitatively to see the presence of phytochemical content in H. Itama honey collected from several areas, including Rimbawan Dalam Tanah Merah Village (Samarinda), Buana Jaya Village (Kutai Kartanegara), Karya Merdeka Village (Kutai Kartanegara) Village, Penajam Village (Penajam Paser Utara) and Saing Prupuk Village (Paser) in East Kalimantan. The detailed result of the qualitative phytochemical analysis of $H$. itama honey is presented in Table 1.

Based on the result in Table 1, flavonoids and coumarin were present in $H$. itama honey collected from all five regions of East Kalimantan. The presence of triterpenoids, steroids, and carotenoids was not observed from honey samples of any sampling area, while alkaloids and tannins 
were observed only in one location. Only $H$. itama honey from Penajam contains alkaloids and tannins from Karya Merdeka and Saing Prupuk. According to Cianciosi et al. (2018) honey has 180 types of compounds. Bakar et al. (2017) reported that $H$. itama honey contains phenolic, flavonoids, and carbohydrates. Based on the results of Syafrizal et al. (2020), H. itama honey has flavonoids, coumarins, and carbohydrates but no triterpenoids, steroids, or carotenoids. H. itama from several regions in Malaysia revealed total phenolic and flavonoid presence, but the highest is Tetratrigona laeviceps (Nasir et al. 2019). The results of Tuksithaa et al. (2018) H. itama from Sarawak quantitatively contained $67.86 \pm 7.40 \mathrm{mg} / \mathrm{mL}$ phenolic 17.67 $\mathrm{mg} / \mathrm{mL}$ flavonoid.

\section{Antioxidant activity}

Heterotrigona itama honey is one of the non-timber forest products currently widely cultivated by honey breeders. Farming of $H$. itama can be found in the form of individuals and groups. The breeding $H$. itama honey bee can be found in the field in the form of individuals and groups. Many consumers are now switching towards the consumption of honey without stinging, one of which is $H$. itama. Based on the results of phytochemical screening (Table 1), the five areas of origin of the honey sampled had flavonoids and coumarin, and some contained tannins and alkaloids, which became necessary for its antioxidant activity. The results of the antioxidant activity test are presented in Table 2. The antioxidant activity of five regions in East Kalimantan was measured by the DPPH test using absorbent spectrophotometry determination in the wavelength range of $524 \mathrm{~nm}$ (Ebrahimzadeh et al. 2009; Saeed et al. 2012). This antioxidant activity determination closely related to the $\mathrm{IC}_{50}$ value is the concentration required to obtain an inhibition value of $50 \%$, which is used as a parameter to express a substance's relative antioxidant capacity. The antioxidant effects of the material depend upon its IC value if it is more than $<50 \mathrm{ppm}$. The estimated value of percent inhibition as a response to an increase in honey concentration can be seen from the linear regression calculations in Table 2.

The results showed that the antioxidant inhibition of $H$. itamahoney from five regions in East Kalimantan increased with increasing honey concentration. These results related to flavonoids, coumarin, and tannins in the honey, as shown in Table 1. The inhibition of free radicals from the $H$. itama honey samples tested increased with the increasing concentration of the honey. The antioxidant activity values of $\mathrm{IC}_{50}$ and the original concentration of $H$. itama honey were 43.54 ppm (Karya Merdeka), $59.91 \mathrm{ppm}$ (Tanah Merah), <25 ppm (Penajam), 61.35 ppm (Buana Jaya) and 71.27 ppm (Saing Prupuk). Syafrizal et al. (2020) stated that $H$. itama from Tanah Merah has flavonoid, coumarin, saponin, tannins, alkaloids, and carbohydrates compounds, and the origin of Tarakan is only saponin compounds that are not present in the honey.

The study of Ghasemzadeh and Ghasemzadeh (2011) showed that the antioxidant activity of honey is influenced by the presence of flavonoids, tannins, and coumarin and has a positive contribution. Another study by Krishmasree and Ukhuru (2015) revealed that the presence of phenolic and flavonoids influences antioxidant activity. Finally, Nayik et al. (2016) stated the presence of phenolic and flavonoids in honey, a source of antioxidant activity.

Table 2. Antioxidant activity of Heterotrigona itama honey from five regions in East Kalimantan, Indonesia

\begin{tabular}{|c|c|c|c|}
\hline Origin of honey & Conc. (\%) & Inhibition (\%) & $\mathrm{IC}_{50}$ \\
\hline $\begin{array}{l}\text { Tanah Merah } \\
\text { (Samarinda) }\end{array}$ & $\begin{array}{l}100 \\
75 \\
50 \\
25\end{array}$ & $\begin{array}{l}68.15 \\
61.35 \\
56.75 \\
19.94\end{array}$ & $59.91 \%$ \\
\hline $\begin{array}{l}\text { Buana Jaya } \\
\text { (Kutai Kartanegara) }\end{array}$ & $\begin{array}{c}100 \\
75 \\
50 \\
25\end{array}$ & $\begin{array}{c}70.70 \\
64.90 \\
57.07 \\
9.26\end{array}$ & $61.87 \%$ \\
\hline $\begin{array}{l}\text { Karya Merdeka } \\
\text { (Kutai Kartanegara) }\end{array}$ & $\begin{array}{c}100 \\
75 \\
50 \\
25\end{array}$ & $\begin{array}{l}71.41 \\
65.62 \\
58.60 \\
37.44\end{array}$ & $43.54 \%$ \\
\hline $\begin{array}{l}\text { Penajam } \\
\text { (Penajam Paser } \\
\text { Utara) }\end{array}$ & $\begin{array}{c}100 \\
75 \\
50 \\
25\end{array}$ & $\begin{array}{l}84.49 \\
76.54 \\
72.64 \\
56.12\end{array}$ & $<25 \%$ \\
\hline $\begin{array}{l}\text { Saing Prupuk } \\
\text { (Paser) }\end{array}$ & $\begin{array}{l}100 \\
75 \\
50 \\
25\end{array}$ & $\begin{array}{c}60.30 \\
50 . .80 \\
41.30 \\
36.07\end{array}$ & $71.27 \%$ \\
\hline Vitamin C & - & - & $\begin{array}{c}32.93 \\
(\mu \mathrm{g} / \mathrm{mL})\end{array}$ \\
\hline
\end{tabular}

Table 1. Phytochemical of Heterotrigona itama honey from five regions in East Kalimantan, Indonesia

\begin{tabular}{|c|c|c|c|c|c|c|c|}
\hline Origin of honey & Alkaloid & Tannin & Flavonoid & Triterpenoid & Steroid & Carotenoid & Coumarin \\
\hline Tanah Merah (Samarinda) & - & - & + & - & - & - & + \\
\hline Buana Jaya (Kutai Kartanegara) & - & - & + & - & - & - & + \\
\hline Karya Merdeka (Kutai Kartanegara) & - & + & + & - & - & - & + \\
\hline Penajam (Penajam Paser Utara) & + & - & + & - & - & - & $\begin{array}{l}\text { T } \\
+\end{array}$ \\
\hline Saing Prupuk (Paser) & - & - & + & - & - & - & + \\
\hline
\end{tabular}


Likewise, Chua et al. (2013) that phenolic and flavonoids found in honey are compounds that play an essential role as antioxidants. Tuksithaa et al. (2018) reported that $H$. itama honey collected from Serawak has $47.40 \%$ inhibition, a high category. Shamsudin et al. (2019a) suggested that $H$. itama's antioxidant activity was good for human health. Furthermore, Shamsudin et al. (2019b) explained that the antioxidant properties in honey depend on the origin of plants and the species of bees. $H$. itama honey from Malaysia showed significant antioxidant activity (Cheng et al. 2019).

\section{Antibacterial activity}

In addition to antioxidants, $H$. itama honey needs another bioactivity test, antimicrobial activity. It is essential because honey is a source of food and health. The $H$. itama honey from five areas in East Kalimantan tested for antibacterial activity with $S$. aureus and $E$. coli are shown in Table 3.

Escherichia coli are pathogenic bacteria that cause infection in humans and animals. These bacteria can be found in soil, water, plants, animals, and humans (Manning 2010). According to Manning (2010), E. coli is an enteric bacteria that can survive in an anaerobic, facultative, and anaerobic atmosphere in the oral cavity, esophagus, stomach, intestines, rectum, and anus.

Morse et al. (2008) stated that Staphylococcus is one gram-positive, non-motile bacteria that do not have spores and lives in groups. Staphylococcus aureus is an anaerobic or microaerophilic commercial microorganism often found in the skin, skin glands, and nose, especially the anterior nerds. Plata et al. (2009) stated that $S$. aureus is a pathogenic microorganism that can infect humans when human immunity decreases.

Based on the present study results, it was observed that $H$. itama honey from five regions has potent inhibition of $S$. aureus and E. coli bacteria. The inhibition zone values for $S$. aureus are $9.89-18.44 \mathrm{~mm}$, and the inhibition zone values for $E$. coli were 9.44-19.11 mm. Pan et al. (2009) classify the inhibitory activities as strong if the inhibition zone is wide, while the inhibition zone is 3-6 mm and the category is more than $6 \mathrm{~mm}$ wide, while the inhibition zone is 3-6 $\mathrm{mm}$ and the category is weak if the inhibition zone was $0-3 \mathrm{~mm}$. The inhibitory activity of $H$. itama honey against $S$. aureus and $E$. coli bacteria is in a strong category because it has flavonoid compounds and some alkaloid and tannin compounds. The same thing was clarified by Sulastrianah et al. (2014) stated that this bacterial activity is influenced by the presence of secondary metabolic compounds, including flavonoids, tannins, terpenoids, and steroid saponins. Tikshitaa et al. (2018) reported that stingless bee honey of $H$. itama from Sarawak could inhibit $S$. aureus and $E$. coli bacteria. There was an inhibition of the activity of $S$. aureus and $E$. coli bacteria because the honey of $H$. itama has phenolic and flavonoid compounds which are polyphenol compounds.

That is due to the presence of the substance of the benzene ring and the saturated side chain in polyphenol, which can affect the activity against bacteria. Flavonoids have antibacterial properties due to the disruption of membrane function or DBA synthesis. The $\mathrm{B}$ ring of flavonoids generally contains hydroxyl $(\mathrm{OH})$ and methoxy (MeO) groups. Mori et al. (1987) reported that the B ring of flavonoids could escalate or form hydrogen bonds with the buildup of nucleic acid bases, which may be an inhibitory force on synthetic nucleic acids in bacteria. Mirzoeva et al. (1997) stated that flavonoids and quercetin could cause an increase in membrane permeability and loss of membrane potential, leading to decreased cell research on antibacterial agents. The results showed that $H$. itama honey from five regions (Tanah Merah, Buana Jaya, Karya Merdeka, Penajam, and Saing Prupuk) as the sampling location had flavonoids and coumarin, but no triterpenoid, steroids, and carotenoids compounds. H. itama honey from Tanah Merah, Buana Jaya, Karya Merdeka, and Saing Prupuk did not contain alkaloids, but those from Penajam contained alkaloids. H. itama honey from Karya Merdeka and Saing Prupuk had tannins, but $H$. itama honey from Tanah Merah Buana Jaya and Karya Merdeka did not have tannins. The antioxidant activity $\left(\mathrm{IC}_{50}\right)$ of $H$. itama honey from five regions was classified as strong to weak. Inhibition of $H$. itama honey from five regions against $S$. aureus and $E$. coli bacteria was a strong category.

Table 3. Antibacterial activity Staphylococcus aureus and Escherichia coli from Hiterotrogona itama honey five areas in East Kalimantan, Indonesia

\begin{tabular}{lcccl}
\hline \multicolumn{1}{c}{ Origin of honey } & $\begin{array}{c}\text { Concentration } \\
(\boldsymbol{\mu} \mathbf{L} / \text { well })\end{array}$ & \multicolumn{2}{c}{ Inhibition $(\mathbf{m m})$} & \multirow{2}{*}{ Antibacterial activity } \\
\cline { 3 - 4 } & 20 & $\boldsymbol{S}$ aureus & $\boldsymbol{E}$ coli & \\
\hline Tanah Merah (Samarinda) & 20 & 18.44 & 11.89 & Strong \\
Buana Jaya (Kutai Kartanegara) & 20 & 11.00 & 18.78 & Strong \\
Karya Merdeka (Kutai Kartanegara) & 20 & 14.48 & 11.33 & Strong \\
Penajam (Penajam Paser Utara) & 20 & 9.89 & 12.44 & Strong \\
Saing Prupuk (Paser) & 20 & 26.11 & 9.44 & Strong \\
Chloramphenicol (positive control) & & & 29.00 & Very Strong \\
\hline
\end{tabular}




\section{ACKNOWLEDGEMENTS}

Our gratitude goes to the head of the Forest Products Chemical Laboratory and Biotechnology Faculty of Forestry, the head of the Agriculture Product Technology Laboratory, Faculty of Agriculture, the head of the Biology Laboratory of the Faculty of Mathematics and Natural Sciences, Mulawarman University and the head of the Research and Standardization Industry center for providing the use of facilities in carrying out this research. Our gratitude to Muhammad Hijrafie, Head of UPTD KPHP Kendilo East Kalimantan Forest service, Syarif Syam "Madu Ratu Trigona." Lalu Fauuzul Idhi "Woodygona," Suwondo "Kelulut Animal Farm" and Rendry Arista Avimaro "Kelulut Park Borneo Etam" as a stingless honey meliponiculture (H. itama and others) who have helped facilitate the sampling location in my research. Thank you to all my friends who helped in carrying out this research.

\section{REFERENCES}

Arung ET, Suwinarti W, Hendra M, Supomo, Kusuma IW, Puteri DCN, Eroglu HA, Kim Y, Shimizu K, Ishikawa H. 2015. Determination of antioxidant and anti-melanogenesis activities of Durio kutejensis [Bombacaceae (Hassk.) Becc] (Indonesian Lai) fruit extract. Trop J Pharmaceut Res 14 (1): 4-46. DOI: 10.4314/tjpr.v14i1.7.

Bakar MFA, Sanusi SB, Bakar FIA, Cong OI, Mian Z. 2017. Physicochemical and antioxidant potential of raw unprocessed honey from Malaysian stingless bees. Pak J Nur 16 (11): 888-894. DOI 10.3923/pjn.2017.888.894.

Ghasemzadeh A, Ghasemzadeh N. 2011. Flavonoids and phenolic acids: Role and biochemical activity in plants and humans. J Med Plan Res 5 (31): 6697-6703. DOI: 10.5897/JMPR11.1404.

Cheng MZSZ, Ismail M, Chan KW, Ooi DJ, Ismail N, Zawawi N, Esa NM. 2019. Comparison of sugar content, mineral element and antioxidant properties of Heterotrigona itama honey from Suburban and forest in Malaysia. Malays J Med Health Sci 15: 104-112.

Chua LS, Rahman NL, Adnan NA, Tan TTE. 2013. Antioxidant activity of three honey samples in relation with their biochemical components. J Anal Method Chem 2013: 1-8. DOI: 10.1155/2013/313798.

Cianciosi D, Forbes-Hernández TY, Afrin S, Gasparrini M, ReboredoRodriguez P, Manna PP, Zhang J, Lamas LB, Flórez SM, Toyos PA, Quiles JL, Giampieri F, Battino M. 2018. Phenolic compounds in honey and their associated health benefits: A review. Molecules 23 (9): 1-20. DOI: 10.3390/molecules23092322.

Ebrahimzadeh MA, Nabavi SF, Nabavi SM. 2009. Essential oil composition and antioxidant activity of Pterocarya fraxinifolia. Pak J Biol Sci 12: 957-963. DOI: 10.3923/pjbs.2009.957.963.

Jayadi LZ, Susandarini R. 2020. Melissopalynological analysis of honey produced by two species of stingless bees in Lombok Island, Indonesia. Nusantara Biosci 12: 97-108. DOI: 10.13057/nusbiosci/n120203.

Krishnasree V, Ukkuru PM. 2015. Phytochemical screening and antioxidant activity of different bee honey. J Med Herbs Ethnomed 1 (1): 38-44. DOI: 10.5455/jmhe.2015-07-013.

Manning SD. 2010. Escherichia Coli Infections. Infobase Publ, New York
Mirzoeva OK, Grishanin RN, Calder PC. 1997. Antibacterial action of propolis some of its components: The effects on growth, membrane potential and motility bacteria. Microbiol Res 152: 239-246. DOI: 10.1016/S0944-5013(97)80034-1.

Mori A, Nishino C, Enoki N, Tawata S. 1987. Antibacterial activity and mode of action of plant flavonoids against Proteus vurgaris and Staphylococcus aureus. Phytochemistry 26: 2231-2234. DOI: 10.1016/S0031-9422(00)84689-0.

Morse SA, Butel JS. 2008. Mikrobiologi Kedokteran Edisi 23. In: Brooks, Jawetz GF, Melnick, Adelberg (Eds.). EGC, Jakarta. [Indonesian]

Nasir NN, Mohd KS, Ibrahim N, Rodi MMM, Zakaria AJ. 2019. Phytochemical analysis and antioxidant activity of honey from three Malaysia stingless bee species. J Agrobiotech 10 (2):1-11.

Nayik GA, Suhag Y, Majid I, Nanda V. 2016. Discrimination of high altitude Indian honey by chemometric approach according to their antioxidant properties and macro minerals. J Saudi Soc Agric Sci 17 (2): 200-207. DOI: 10.1016/j.jssas.2016.04.004.

Oscar S, Antonio C, Marina G, Elsa R, Gabriel V. 2020. Phytochemical screening, antioxidant activity, and in vitro biological evaluation of leaf extracts of Hyptis suaveolens (L.) Poit. South Afr J Biol 128: 6266. DOI: 10.1016/j.sajb.2019.10.016.

Pan X, Chen F, Wu T, Tang H, Zhao Z. 2009. The acid, bile tolerance and antimicrobial property of Lactobacillus acidophilus NIT. Food Control 20 (6): 598-602. DOI: 10.1016/j.foodcont.2008.08.019.

Plata K, Rosato AE, Wegrzyn G. 2009. Staphylococcus aureus as an infectious agent: overview of biochemistry and molecular genetics of its pathogenicity. Acta Biochemica Polonica 56 (4): 597-612. DOI: 10.18388/abp.2009_2491.

Saeed N, Khan MR, Shabbir M. 2012. Antioxidant activity, total phenolic and total flavonoid contents of whole plant extract Torilis leptophylla L. BMC Compl Altern Med 12: 221 DOI: 10.1186/1472-6882-12221.

Shamsudin S, Selamat J, Sanny M, Razak ABA, Jambari NN, Khatib A. 2019a. A comparative characterization of physicochemical and antioxidants properties of processed Hiterotrigona itama honey from different origins and classification by chemometrics analysis. Molecules 24: 1-20. DOI: 10.3390/molecules24213898.

Shamsudin S, Selamat J, Sanny M, Razak BAS, Jambari NN, Mian Z, Khatib A. 2019b. Influence of origins and bee species on physicochemical, antioxidant properties and botanical discrimination of stingless bee honey. Intl J Food Prop 22 (1): 339-264. DOI: 10.1080/10942912.2019.1576730.

Sulastrianah, Imran, Fitria ES. 2014. Inhibitory test of leaf extracts (Annona muricata L.) and sirih (Piper betle L.) against the growth of Escherichia coli bacteria. Medula 1 (2): 76-84. DOI: 10.46496/medula.v1i2.197. [Indonesian]

Syafrizal, Tarigan D, Yusuf R. 2014. Keragaman dan habitat lebah Trigona pada hutan sekunder tropis basah di hutan pendidikan lempake, Samarinda, Kalimantan Timur. J Teknologi Pertanian 9 (1): 34-38. [Indonesian]

Syafrizal, Ramadhan R, Kusuma IW, Egra S, Shimizu K, Kanzaki M, Arung ET. 2020. Diversity and honey properties of stingless bees from meliponiculture in East and North Kalimantan, Indonesia. Biodiversitas 21 (10): 4623-4630. DOI: 10.13057/biodiv/d211021.

Tuksithaa L, Chen YLS, Chen KY, Wong KY, Peng CC. 2018. Antioxidant and antibacterial capacity of stingless bee honey from Borneo (Sarawak). J Asia-Pac Entomol 21: 563-570. DOI: 10.1016/j.aspen.2018.03.007.

Viji GS, Vasanthe B, Suresh K. 2013. Screening and antibacterial activity analysis of some important medicinal plants. Int J Innov Appl Stud 2 (2): 146-152. 